\title{
The role of the Dyson model for strategic development in achieving strategic success / case study in Baghdad Municipality
}

\author{
Prof. Dr. Fadheelah Salman dawood \\ dr.fadhiela.salman@coadec.uobaghdad.edu.iq
}

\begin{abstract}
Ali Salah Abood Mahmoud
Ali.Mahmoud13033@coadec.uobaghdad.edu.iq

Abstract:

This research aims to identify the role of the Dyson model for strategic development in achieving strategic success, and the starting point of the research was the following main question: What is the role of the Dyson model in achieving success?

The research was applied in the field in the departments of the Baghdad Municipality, where the examination list was relied upon, which included a set of questions that the senior and middle leaders in the Baghdad Municipality answered, and it was the main means by which the information related to the field of research was collected, and the checklist included two variables and three dimensions From each variable, as each dimension included four questions that express indicators that revolve around one of the research hypotheses, and the case study methodology was used, which defined its path and steps, collected and analyzed field data, and linked it to its theoretical framework, in order to reach To achieve the goal of completing this research, and through analyzing, interpreting and discussing the results, the most important results were drawn up: It was found that the principle of motivation within the departments of Baghdad Municipality does not exist and this affects the employees who do not receive it from the higher leaders in their departments, and this shows that the leaderships in The Municipality of Baghdad do not have the skills and experience. Baghdad Municipality seeks to work alone and not to involve employees who have experiences and skills and strive to achieve development in their departments, and this is what the community members expressed. Among them and poor business completion in their departments.
\end{abstract}

Key words: Dyson Development Model, Strategic Success, Baghdad Municipality

The first topic

\section{Scientific methodology}

\section{First: the research problem: -}

The problem of research is embodied in the departments of the Baghdad Municipality, especially in the service sector, and it is known that the Municipality of Baghdad is responsible for the cleanliness, aesthetics and development of the city, as there is a big problem, which is mismanagement by some leaders in addition to the challenges, and it needs a lot of efforts and intellectual and practical contributions. To meet these challenges that hinder the process of its development and achieve its successes, and then rise to an acceptable level of efficiency and effectiveness, and this is done by applying the Dyson model role approach to development as well as the possibility of exploring the requirements for achieving strategic success, which increases the ability to face current and future problems and challenges related to activities, investment, and social and Al-Iqtisadiah became an obligation for the Municipality of Baghdad to adopt such concepts to achieve its success and with a strategic perspective. This is in order to be able 
to keep pace with progress and to find a foothold in the ranks of developed countries with steady steps and a clear vision with challenging and applicable characteristics that would advance the current service reality and explore ways to face future challenges, and in order to be accurate in finding adequate solutions to the research problem, that the aim of the research is Emphasis on formulating accurate questions, more than finding correct answers to them, and these questions are determined in:

A- What is the nature and level of exclusion of each Dyson model for strategic development and success in the Baghdad Municipality research community?

$B$ - Is there a correlation between strategic development and strategic success?

C-Is there an impact of the dimensions of strategic development on strategic success?

\section{Second: The importance of research ...}

The management of organizations emphasizes the importance of strategic development as an important tool through which it is able to perceive developments and changes and respond to environmental changes, and adapt to its requirements by maximizing the use of opportunities and avoiding the risks and challenges generated by the dynamism of this environment. Strategy, as it has become a pivotal goal for many organizations to ensure its continuity and achieve its strategic success. Which is summarized by the following data:

1. The importance of research is embodied in two dimensions: The first is theoretical, which is to contribute to enhancing the conceptual presentation of intellectual frameworks and treatments related to the research variable and its dimensions. The second dimension is applied, which is analyzing the implications of the reality and investigating its trends in the field in the departments of the Baghdad Municipality.

2. The research provides a database and information that can be used in the Baghdad Municipality to meet the current and future changes, and enable it to update its working methods and structures to increase its efficiency and effectiveness and achieve the strategic success of the organization.

3. The importance of the research lies in the need for the Baghdad Municipality to understand the theoretical concepts and practical practices of strategic development. And the benefits of it.

\section{Third: The objectives of the research}

1 - Identify the strategies of the Dyson model for strategic development in achieving strategic success, as important variables in the management of public organizations

2- Shedding light on the most important dimensions of strategic development in the Baghdad Municipality

3-Clarify the nature of the relationship and the impact of the Dyson model for strategic development on strategic success in the Baghdad Municipality departments.

\section{Fourth: The hypothetical outline of the research}


The figure below shows the hypothetical scheme of the research, as it shows a set of logical relationships between the main and sub-variables, as well as clarifying the main and subsidiary research variables, and the chart consists of two variables, one independent and the other dependent, which is as shown below:

The independent variable: represented by the (Dyson) model for development and it consists of the following dimensions

\section{1- Strategic direction}

2- Performance Measurement (BSC)

3- Strategic Analysis (SWOT)

$B$ - The dependent variable: represented by strategic success - and it consists of the following dimensions:

1- Staying

2- Adaptation

3- A specific strategy

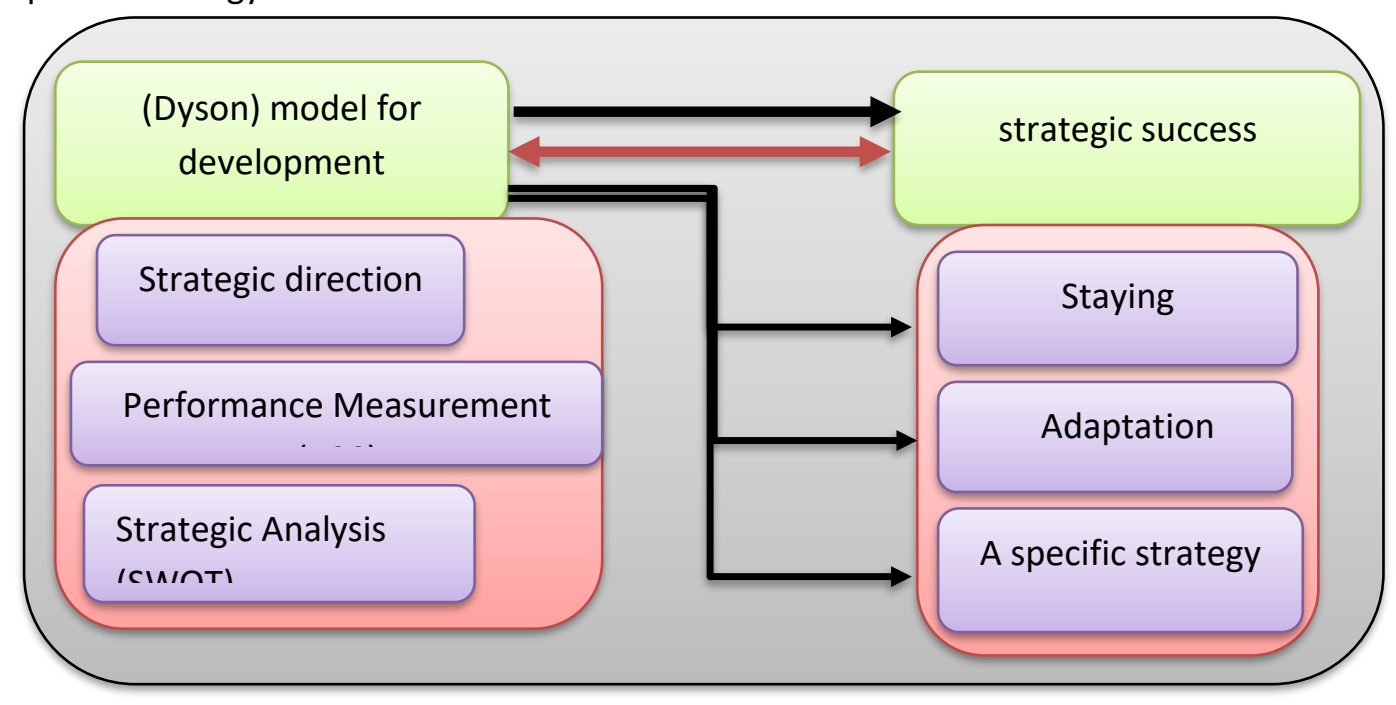

Figure () Study Model

Fifth: Research hypotheses...

Does the Dyson model for strategic development contribute to the success of the Baghdad Municipality?

\section{Sixth: Research Limits:}


1- The current research: includes the headquarters of the Baghdad Municipality and some departments affiliated to it. In addition (the Municipality of Al-Karkh Center and the Municipal Department of AlRusafa Center have been selected).

2- Temporal boundaries: It is represented by the period of preparation of field research in the Baghdad Municipality and included (Baghdad Mayor Office / Investment Department, Baghdad Mayor Office, Comprehensive Quality Department, Planning and Follow-up Department, Supervision and Auditing Department, Rusafa Center Municipal Department and Al-Karkh Municipality Department), which extended for the period between (1/15/2021) until (3/23/2021), this period includes the researcher's visits to the Baghdad Municipality to collect data and information about the research community.

\section{Seventh: Research tools ...}

1- The theoretical aspect: In dealing with the theoretical aspect, the researcher relies on the literature of strategic thought in strategic success and development, including books, foreign and Arab research, and international research from research and from Arab periodicals and magazines.

2- Checklist: It is a formula that was prepared for collecting and recording data in an easy and direct way, to suit the type of data required to be collected and in groups classified according to the purpose of the research. By the researcher and seeing the nature of the work of each of them, an intentional sample was taken, represented by the general directors, assistants, heads of departments, directors of the people, and officials of the units.

\section{Eighth: The research sample and its characteristics}

The research sample includes the higher and middle administrative leaderships of the Baghdad Municipality, represented by (Director General, Assistant Director General, Heads of Departments, People Managers, and unit officials). They possess the cultural and their expertise by virtue of their administrative positions that they undertake, in addition to that they are responsible for taking decisions within the Baghdad Municipality.

\section{The second topic}

\section{Theoretical framework}

\section{First: Dyson's model for development}

The research aims to identify the possibility of adopting the strategic development approach according to a number of dimensions of the (Dyson) model by diagnosing the reality of services in the Baghdad Municipality departments according to the dimensions of the model and the extent of their need to adopt strategic development. The administration in the Municipality of Baghdad, which was confirmed by the field visits conducted by the researcher with the general directors, assistants, heads of departments, people directors and unit officials. 


\section{First: the concept of strategic development}

The concept of strategic development is an acronym that adopts a creative and innovative way of thinking, in which the planning and implementation factor enters together in order to achieve the objectives of the organization in the presence of studied risk and uncertainty. (Al-Ghanim, 3: 2020), that strategic planning or strategy formulation is part of strategic development, as strategic development is the most comprehensive umbrella and includes all stages of planning, formulating and implementing the strategy, its evaluation and feedback. A well-formulated strategic plan, except after a careful analysis of the internal and external environment of the organization, (Al-Ghalbi and Idris 27: 2015) emerged as a fruit of global developments, and as an effective means that enables the administration to play its role by developing traditional management thinking, facilitating procedures, and The use of technology (Fathallah 2012: 62) and they refer (Amer and Qandil 2010: 243), to the scientific and practical nature of strategic development, and summarize (Abu Al-Ward 2015: 44) that the concept of strategic development depends on several pillars, which are as follows:

1- The planned, organized and comprehensive effort is for all components of the organization.

2-It is based on a long-term plan that focuses on improving the internal environment of the organization and increasing organizational effectiveness.

It is an ongoing process that organizations resort to to modify their strategic path by making fundamental changes in their work, and the way in which they compete, in order to improve their performance and maintain their competitive position with the passage of time.

second: The importance of strategic development -

The importance of strategic development as he sees it (Al-Barasy 39: 2015) is as follows:

1. Supporting the efficiency of the organization, increasing efficiency, raising productivity in quantity and quality, and reducing waste of resources.

2. Work on the integration of the objectives of the organization, society, and work.

3. Take advantage of developments and discoveries in the field of other sciences.

4. There is a weakness in the supervisory methods of work performance.

There is a separation between employees and management, their absenteeism, increased complaints, and low morale (Al-Salam and Adel: 2006, 43) And indicating (Al-Qasim, 2015: 111.110) of the importance of strategic development in the following aspects:

1. Supporting the efficiency of the organization, increasing its effectiveness, raising productivity in quantity and quality, and reducing waste of resources.

2- Developing human forces, improving their performance, upgrading their behavior, and fueling creativity and innovation. 
And that the importance of strategic development is due to many reasons, as he sees it (Amari, 2013: 43), as it is as follows:

1. Makes proactive efforts of the organization to address strategic mistakes before they happen.

2. Links the performance learning process with the overall planning process, allowing strategic business plans to align with human resource plans.

\section{Third: - Dimensions of strategic development}

The dimensions have been known ((as an estimate of a value around which the majority of data are centered and represented by the best representation)) (Samhan, 2010: 71). When talking about strategic development, we find that there are difficulties facing these, represented by the lack of studies that dealt with measuring strategic development, especially public organizations, and as identified The basic dimensions of strategic development according to the Dyson model of strategic development, and the following is a discussion of a number of those dimensions that were dealt with in the research as follows:

\section{1- Strategic direction (strategic vision and objectives)}

Defining the strategic direction includes defining the vision for the strategic development process, achieving the strategic logic, the structure of the problem, and building the strategic agendas in the negotiations. Hence, it is necessary to consider the strategic vision for strategic development in terms of the concept (dyson 2007). Taking direct strategic initiatives for implementation is the path of intuition, hope and strategy. Emerging with all its limits. It is an incremental corrective used interactively when unintended consequences arise and corresponds to a "single learning loop," (Argyris \& Schon 1978).

\section{2- Measuring performance using the Balanced Scorecard - BSC}

Performance measurement is one of the topics that attract a lot of attention, whether in the academic or the practicing world, and (2006: 22 Neely) notes that performance measurement is a diverse topic because researchers who participate in its study come from a variety of backgrounds, from accounting and operations management to psychology, sociology and economics. It is believed that the basic principle behind the interest in performance measurement is that "what is measured is what is actually accomplished" (Dimitrakopoulos, 2018: 37) has defined the concept of performance measurement, which is a measure of performance used to measure the efficiency or effectiveness of an action while the performance measurement system is a "group of Metrics used to measure actions taken in the organization.

\section{3- Strategic analysis of the internal and external environment - SWOT}

A SWOT analysis aims to identify the strengths and weaknesses of the organization and the opportunities and threats in the environment. Where these factors are identified whose strategies have been developed which may build on strengths, eliminate weakness, and invest opportunities or challenges, (Dyson 2004) that the focus that SWOT creates is neither deterministic nor complete in any way, but it was found useful and when it is done. It is used effectively (usually within a group process in the 
organization), and is insightful in forming strategy (Dyson 2007: 11) and (Hodgkinson, 2006: 476--496) believes that strategic analysis is a process that ensures the monitoring of the organization's environment.

\section{Second: strategic success}

\section{First: the concept of strategic success}

There are a large number of organizations that have tended to form strategic alliances to ensure their survival and success in their work (Al-Tamimi and Al-Khashali, 2015: 646), that the concept of success in organizations is related to environmental adaptation and growth and thus the achievement of survival, as continuity and interaction under the changing environment requires flexibility and creating a state of Balance, and in order to achieve this, it is necessary to find a scale to evaluate the organization's performance so that it fits with each stage of the organization's life cycle (Al-Halamah and Al-Azzawi 2009: 22). As for (Thomas, 2013: 3), strategic success is seen as the successful administrative leadership that fulfills the objectives of the organization and what It occurs in the business environment, and faces reality with a valuable view of the customer and all the owners of the organizations, and (Alundawy, 2012: 25) defined strategic success as the ability of the organization to achieve its long-term goals by keeping pace with environmental developments and changes related to the needs of the organization dealing with it as required by the organizations that seek To achieve success in identifying the strengths and weaknesses in the target areas and improving them by studying and testing their dimensions. The information gathered is used in the formulation of the strategy on the $n$ True ho, (Hesham \& Magd, 2007: 65).

\section{Second: - The importance of the strategic success of organizations.}

Strategic success is very important for organizations in light of the goals that independent bodies seek to achieve, and it is a set of reasons that achieve excellence, leadership, efficiency and organizational effectiveness (

Al-Lafi and Al-Khashman: 51: 2019) and among the factors that contributed to the increase in the importance of managing the organization, which is the expansion of the governmental role, the increase in the spread of administrative problems in government organizations, technological developments, and the increase in the preparation of students for management science (Al-Khafaji and Al-Hayti, 2009: 3634), and confirmed Al-Tamimi and Al-Khashali 646: 2015) stated that all organizations are working to achieve success in their work by building organizational capabilities and vital competencies (core competencies), while Jones, 2010: 13) \{The strategy is easy to formulate, but difficult to implement\}.

\section{Third: the dimensions of strategic success}

The theories acquire the character of application and testing to prove the validity of the adopted hypotheses, as they indicate the paths of relationships between the dimensions of the studied phenomena and their correlations with closer ones (Al-Saadi, 2010: 16-17). There is a question that arises, what are the dimensions or measures of success? Both (2007: 493: Katz \& Green) answered this question that the measure of success for a short period is, \{profitability\} and for a long time is \{survival\}, and therefore it 
includes facing challenges, and that the key to any new organization is to identify in a way that helps it survive and for its own sake. Proof of their worth and projects must make profits (Katz \& Green, 2007: 586).

\section{1- Survival: -}

(Al-Rikabi, 2004: 347) referred to survival as the essence of strategic success, and the organization is judged to be successful by remaining in the competition circle. Staying in the competition field is a goal that all organizations seek and may require them to take care of the interests of all parties involved with the organization, including investors. And suppliers, customers and workers, and concludes (Al-Dulaimi 101: 2013) from that (that staying in the business field is the goal of the organization and is achieved through achieving the following sub-objectives $\}$ :

A - The organization's ability to achieve the goals of society in addition to achieving its goals.

$B$-Attention to the interests of all parties related to the organization.

\section{2- Adaptive:}

This type of change is referred to as distinct and requires the organization's response to maintain the competitive advantage, and some distinct change may be described as a change that affects the organization according to a radical and organizational change (Al-Enazi, 2010: 126) and defined it (Kasten, 2006: 20) as the effort The organizer to respond to a changing environment. "He defined it (Hammoud, 329: 2010) as " the degree of the organization's ability to predict the internal and external problems that it will face in the future and find ways to control it as much as possible. "And he defined it (Al-Rikabi, 2004: (342) as \{the secret of success. The organizations' strategic ability to adopt the adaptive pattern of their activities with the environmental changes and their remaining active in them\}.

\section{3- A specific strategy}

An organization without a strategy is like a ship without a wave that rotates in a closed loop, it is like an irregular boat that does not know where to go (Daft, 2001: 3) For the purpose of success in the real world, the planning environment in the organization must be open in order to receive indicators of change, and receive warnings The potential need for change in tactics and approaches (Abu Rdan, 2005-18: 17), and these are often fulfilled

The organizations have the goals set for them, as the clarity of the strategy and the definition of its vision secures success in its implementation. He also emphasized (Al-Halamah and Al-Azzawi, 122: 2009) that successful organizations are interested in formulating a clear and specific strategy, while failed organizations get stuck in the formulation of their strategy.

\section{The third topic}

\section{Practical side}


First: - An overview of the history of the Baghdad municipality before the establishment of the Capital Municipality.

The municipality is the vital part related to people's lives, by providing the necessary services that the modern city needs, so it must be formed according to a system that achieves the desired goal, which is to raise a level comparable to the level of high-end countries. The first municipality was established in Baghdad in 1868 AD, when a set of provisions for the municipality law (the municipality of Nizamnama C) was issued and headed by Ibrahim Effendi Al-Daftari, when the Ottoman government's interest in establishing municipalities in the Ottoman Empire began in the year 1845, when the Supreme Council for Reform decided to form a committee to prepare a study On the municipal systems and the rules for their formation in European countries, where the Municipality of the Capital was established in February 1923, and the Municipality of Baghdad is the government agency responsible for the capital of the Iraqi Republic, Baghdad.

Second: Description of the research sample responses according to a checklist of the main and sub variables

This topic aims to evaluate the performance of Baghdad Municipality departments according to a checklist through personal interviews with a number of senior leaders, as it can be said that the Baghdad Municipality needs a lot of improvement in its institutional performance, as the researcher found through the interviews and observations that the researcher witnessed in the departments Municipality of Baghdad, being one of the employees of the Municipality, with the ability to move between all the departments of the Municipality and obtain data and information in this field. The checklist will now be analyzed using the Likert scale, which is proportional to the sample using weights (not applied, not documented (0) not applied, partially documented, (1) not applied, fully documented, (2), partially, applied, partially, documented, (3), fully, applied, not documented). 4) Fully Implemented Partially Authenticated (5) Fully Implemented Fully Authenticated ((6) This is what has been observed on the ground as most of the procedures are partially documented without actual implementation.

\section{First: Dyson's model for development}

1- Strategic direction: The direction towards the strategic direction in general in the administration focuses towards

Focusing on the main strategic aspects instead of focusing on the tactical aspects. This has been reflected in the activities of the management of organizations. This criterion includes (4) questions distributed into (6) weights related to (the existence of an integral relationship between the vision and the strategic objectives to support strategic development) and as shown in the special checklists By applying and documenting the skill standard described in Table (1) below. 


\begin{tabular}{|c|c|c|c|c|c|c|c|}
\hline Strategic Direction & 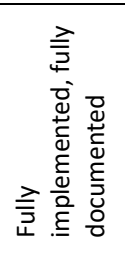 & 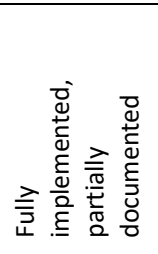 & 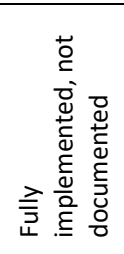 & 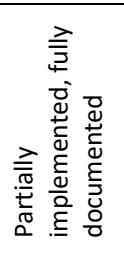 & 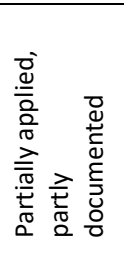 & 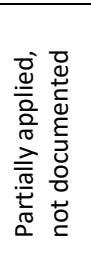 & 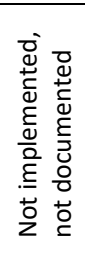 \\
\hline & 6 & 5 & 4 & 3 & 2 & 1 & $\mathbf{0}$ \\
\hline $\begin{array}{l}\text { The Municipality of Baghdad is keen on the } \\
\text { existence of an integral relationship between } \\
\text { the vision and the strategic objectives to } \\
\text { support strategic development. }\end{array}$ & & & & & $\checkmark$ & & \\
\hline $\begin{array}{l}\text { The Baghdad Municipality has a structure to } \\
\text { define the problem and build strategic } \\
\text { agendas in the municipality departments. }\end{array}$ & & & & $\checkmark$ & & & \\
\hline $\begin{array}{l}\text { The Municipality of Baghdad adopts specific } \\
\text { mechanisms and methods in determining } \\
\text { objectives and naming aspects of their } \\
\text { importance, benefits and types. }\end{array}$ & & & & & $\checkmark$ & & \\
\hline $\begin{array}{l}\text { Baghdad Municipality seeks to define the } \\
\text { vision and identify problems }\end{array}$ & & & & $\checkmark$ & & & \\
\hline Duplicates & 0 & $\mathbf{0}$ & $\mathbf{0}$ & 2 & 2 & $\mathbf{0}$ & $\mathbf{0}$ \\
\hline Score $=$ iterations $x$ weights & $\mathbf{0}$ & 0 & 0 & 6 & 4 & 0 & $\mathbf{0}$ \\
\hline $\begin{array}{l}\text { Weighted arithmetic mean = result range } / \\
\text { group of iterations }\end{array}$ & \multicolumn{7}{|c|}{2.5} \\
\hline $\begin{array}{l}\text { Match extent }=\text { arithmetic } \text { mean } / \text { highest } \\
\text { weight }\end{array}$ & \multicolumn{7}{|c|}{0.416} \\
\hline Gap Size = 1- Percentage of match extent & \multicolumn{7}{|c|}{0.584} \\
\hline
\end{tabular}

The results of Table (1) show that after the strategic orientation, it obtained a rate of (2.5) and that the percentage of the extent of conformity is (42\%), which indicates a gap of non-conformity at a rate of 58\%). This is because the Municipality of Baghdad does not have a strategic approach to deal with environmental changes, and it also does not have the ability to reformulate its plans to suit the current requirements, resulting from all of the following:

1. Weak strategic measures to be taken when strategic development is required.

2. Delay in updating the organizational structure of the Municipality of Baghdad when required.

\section{Areas for improvement required}

A-Development of a change program that focuses on both the structural change in the fabric of the institution and the culture required for leadership, and supporting that within the organization.

$B$ - The limited financial allocation of the Municipality of Baghdad to support the comprehensive strategy and development of structures for municipal departments. 
2- Performance measurement: Within the performance appraisal, there is a comprehensive view of the employee's performance and achievements. The current performance is compared to his previous performance and what it includes in terms of skills, knowledge and initiative to achieve the organization's vision and goals. As the performance evaluation shows the employee's ability to assume a higher level of tasks and responsibilities. This criterion includes (4) questions distributed into (6) weights related to (an effective performance appraisal system based on standards of expertise and competence) and as shown in the checklists for the application and documentation of the skills standard, which is illustrated In Table (2) below.

\begin{tabular}{|c|c|c|c|c|c|c|c|}
\hline \multicolumn{8}{|c|}{ Table (2) the performance measurement checklist } \\
\hline performance measurement & 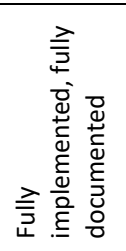 & 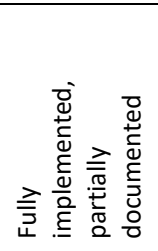 & 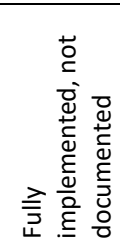 & 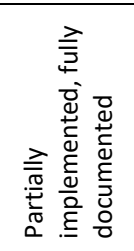 & 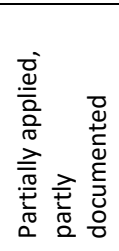 & 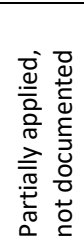 & 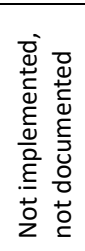 \\
\hline & 6 & 5 & 4 & 3 & 2 & 1 & $\mathbf{0}$ \\
\hline $\begin{array}{l}\text { The Municipality of Baghdad adopts an } \\
\text { effective performance evaluation system } \\
\text { based on standards of expertise and } \\
\text { competence }\end{array}$ & & & & $\checkmark$ & & & \\
\hline $\begin{array}{l}\text { The personnel performance appraisal system } \\
\text { helps to select candidates to fill positions from } \\
\text { within the Municipality of Baghdad. }\end{array}$ & & & & & $\checkmark$ & & \\
\hline $\begin{array}{l}\text { The employee performance appraisal system } \\
\text { provides an information base that is useful in } \\
\text { formulating and setting human resources } \\
\text { policies }\end{array}$ & & & & $\checkmark$ & & & \\
\hline $\begin{array}{l}\text { The employee performance appraisal system } \\
\text { contributes to developing employee skills and } \\
\text { capabilities. }\end{array}$ & & & & $\checkmark$ & & & \\
\hline Duplicates & $\mathbf{0}$ & $\mathbf{0}$ & $\mathbf{0}$ & 3 & 1 & $\mathbf{0}$ & $\mathbf{0}$ \\
\hline Score $=$ iterations $\times$ weights & $\mathbf{0}$ & $\mathbf{0}$ & $\mathbf{0}$ & 9 & 2 & $\mathbf{0}$ & $\mathbf{0}$ \\
\hline $\begin{array}{l}\text { Weighted arithmetic mean = result range } / \\
\text { group of iterations }\end{array}$ & & & & 2.75 & & & \\
\hline $\begin{array}{l}\text { Match extent = arithmetic mean } / \text { highest } \\
\text { weight }\end{array}$ & & & & .687 & & & \\
\hline Gap Size = 1- Percentage of match extent & & & & .313 & & & \\
\hline
\end{tabular}

The results of the checklist in Table (2) above indicate that the Baghdad Municipality has achieved an average of (2.75) out of (6). This rate indicates that the Baghdad Municipality has reached a nonapplied level partially documented from the paragraphs of the performance measurement standard with 
an application rate of (69) \%), Which indicates the existence of a mismatch gap of (31\%), and this indicates the existence of a clear gap resulting from each of the following:

1- The absence of a real system that evaluates the performance of individuals working in developing their skills and abilities.

2- The lack of a system for evaluating the performance of individuals for selecting candidates to fill positions from within the Municipality of Baghdad.

Areas for improvement required

A-Creating a real system that evaluates the performance of working individuals and develops their skills.

B-Selection of qualified candidates to fill the positions within the Baghdad Municipality

3- Strategy for analysis: - The strategic analysis of the environment is based on analyzing the internal and external components of the organization's environment, in order to reach the strengths and weaknesses in its internal environment, and to discover opportunities that can be invested and threats that hinder the organization's work in its external environment. The management uses it to determine the extent of change in the external environment and to determine the competitive advantage or distinctive efficiency of the organization in controlling its internal environment, so that this contributes to increasing the ability of the top management to define its objectives and its strategic position, and this criterion includes (4) questions distributed into (6) weights related to (By obtaining the best strategic analysis to find strengths and weaknesses) and as shown in the checklists for the application and documentation of the strategic analysis standard, as shown in Table (3) below.

\begin{tabular}{|c|c|c|c|c|c|c|c|}
\hline \multicolumn{8}{|c|}{ Table (3) Analysis strategy checklist } \\
\hline Analysis strategy & 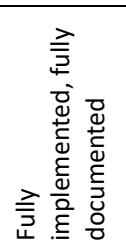 & 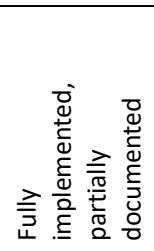 & 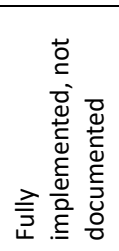 & 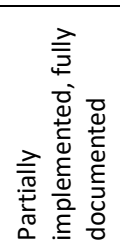 & 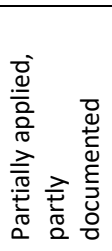 & 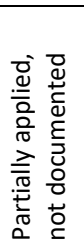 & 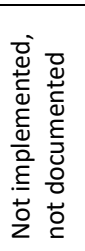 \\
\hline & 6 & 5 & 4 & 3 & 2 & 1 & 0 \\
\hline $\begin{array}{l}\text { The Municipality of Baghdad is seeking by } \\
\text { formulating a new strategy that leads to the } \\
\text { realization of its investments }\end{array}$ & & & & $\checkmark$ & & & \\
\hline $\begin{array}{l}\text { Some of the changes in the Baghdad } \\
\text { Municipality require experts from outside the } \\
\text { Baghdad Municipality. }\end{array}$ & & & & $\checkmark$ & & & \\
\hline $\begin{array}{l}\text { The primary objectives of the Baghdad } \\
\text { Municipality is to obtain the best strategic } \\
\text { analysis to find strengths and weaknesses. }\end{array}$ & & & & $\checkmark$ & & & \\
\hline
\end{tabular}




\begin{tabular}{|c|c|c|c|c|c|c|c|}
\hline $\begin{array}{l}\text { Senior management cuts down on activities } \\
\text { that do not add any value to the business }\end{array}$ & & & $\checkmark$ & & & & \\
\hline Duplicates & 0 & $\mathbf{0}$ & 1 & 3 & 0 & 0 & $\mathbf{0}$ \\
\hline Score $=$ iterations $\mathrm{x}$ weights & 0 & 0 & 4 & 9 & 0 & 0 & $\mathbf{0}$ \\
\hline $\begin{array}{l}\text { Weighted arithmetic mean = result range } / \\
\text { group of iterations }\end{array}$ & \multicolumn{7}{|c|}{3.25} \\
\hline $\begin{array}{l}\text { Match extent = arithmetic mean } / \text { highest } \\
\text { weight }\end{array}$ & \multicolumn{7}{|c|}{0.541} \\
\hline Gap Size = 1- Percentage of match extent & \multicolumn{7}{|c|}{0.459} \\
\hline
\end{tabular}

The results of the checklist for the strategic analysis standard in Table (3) showed that the Municipality of Baghdad achieved an average of (3.25) out of (6). This rate indicates that the Baghdad Municipality has reached the level of non-implementation and the complete documentation of the paragraphs of the strategic analysis standard with an application rate of (54\%), meaning a gap of (46\%), that is because the Baghdad Municipality does not have a system of basic objectives and to obtain the best strategic analysis to find strengths and weaknesses, and this indicates that there are reasons for each of the following:

1 Lack of highly skilled personnel to find strengths and weaknesses.

2 Lack of a clear strategist.

\section{Areas for improvement required}

A-Defining and assessing the opportunities and threats that the Baghdad Municipality can provide to the external environment and the strengths and weaknesses contained in the internal environment.

B - The Municipality of Baghdad should benefit from the results of the strategic analysis in determining the main strategic directions of the organization.

\section{Second: Strategic Success:}

1- Survival: This criterion clarifies how the Baghdad Municipality defines training plans to compete with other departments and adopt a system to receive the opinions and complaints of citizens for the purpose of continuing their service and developing its service performance (4) questions distributed into (6) weights related to (how to build new ideas that guarantee their survival first. Then development) and as shown in the checklists for the application and documentation of the survival criterion, which is illustrated in Table (4) below: 


\begin{tabular}{|c|c|c|c|c|c|c|c|}
\hline Survival & 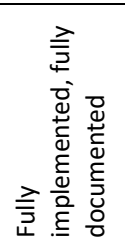 & 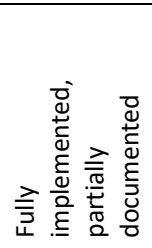 & 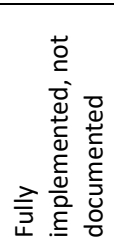 & 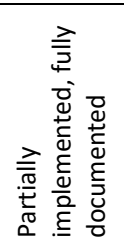 & 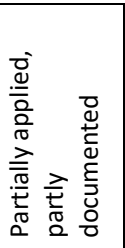 & 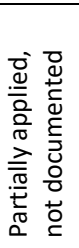 & 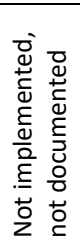 \\
\hline & 6 & 5 & 4 & 3 & 2 & 1 & $\mathbf{0}$ \\
\hline $\begin{array}{l}\text { Has the Baghdad Municipality adopted a } \\
\text { system to receive the opinions and complaints } \\
\text { of citizens for the purpose of continuing their } \\
\text { service and developing its service } \\
\text { performance? }\end{array}$ & & & $\checkmark$ & & & & \\
\hline $\begin{array}{l}\text { Secretariat departments implement training } \\
\text { plans to compete with other departments }\end{array}$ & & & & $\checkmark$ & & & \\
\hline $\begin{array}{l}\text { Did the Municipality of Baghdad seek to adopt } \\
\text { new ideas that guarantee its survival first and } \\
\text { then develop its services in the future? }\end{array}$ & & & & $\checkmark$ & & & \\
\hline $\begin{array}{l}\text { Has the Municipality of Baghdad sought to } \\
\text { increase its business by continuing and } \\
\text { improving its services? }\end{array}$ & & & $\checkmark$ & & & & \\
\hline Duplicates & $\mathbf{0}$ & $\mathbf{0}$ & 2 & 2 & & & $\mathbf{0}$ \\
\hline Score $=$ iterations $\mathrm{x}$ weights & $\mathbf{0}$ & $\mathbf{0}$ & 8 & 6 & & & $\mathbf{0}$ \\
\hline $\begin{array}{l}\text { Weighted arithmetic mean = result range } / \\
\text { group of iterations }\end{array}$ & \multicolumn{7}{|c|}{3.5} \\
\hline $\begin{array}{l}\text { Match extent }=\text { arithmetic } \text { mean } / \text { highest } \\
\text { weight }\end{array}$ & \multicolumn{7}{|c|}{0.583} \\
\hline Gap Size = 1- Percentage of match extent & \multicolumn{7}{|c|}{0.417} \\
\hline
\end{tabular}

The results of the checklist for the survival criterion in Table (4) showed that the Baghdad Municipality has achieved an average of (3.5) out of (6). This rate indicates that the Baghdad Municipality has reached a non-applied level, and the overall documentation of the paragraphs of the survival criterion has reached an application rate of (58). \%) That is, with a gap of (42\%). This is because the Baghdad Municipality has a difficult routine management system, so it requires the higher departments in the Baghdad Municipality to pay more attention to the strategic plan and in accordance with the vision that it seeks to reach, although detailed plans are in place, but there is no complete implementation it is hoped to avoid In the future, this indicates that there are reasons for each of the following:

a. Not formulating a strategy for the Baghdad Municipality for the purpose of ensuring its survival first and then developing its services in the future, but there is no monitoring of the implementation of those plans.

B. Lack of development of policies, strategies, contexts used in the Baghdad Municipality.

Areas for improvement required 
a. The need for more information about survival and the endeavor to increase its business through continuity and improvement of its services.

B. Developing a vision for the Municipality of Baghdad, transforming it into tangible results, and developing its goals and mission.

2- Adaptation: Adaptation is one of the important characteristics of organizations and has great importance and high value in the success of the organization. Employers are looking for employees who have a high coping ability, because of the positive results that follow, such as their excellent work performance, their attitude towards their work and the ability to deal with stress, and this criterion includes (4) questions distributed into (6) weights related to (pre-adaptation). To work before starting the implementation to reduce errors, develop emergency plans and develop institutional work skills) and as shown in the checklists for the application and documentation of the adaptation standard, which is illustrated in Table (5) below:

\begin{tabular}{|c|c|c|c|c|c|c|c|}
\hline \multicolumn{8}{|c|}{ Table (5) Adaptation Checklist } \\
\hline Adaptation & 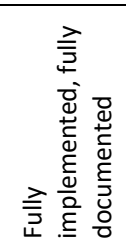 & 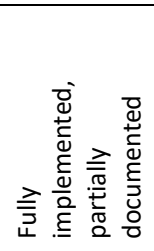 & 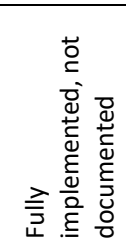 & 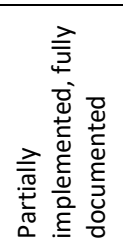 & 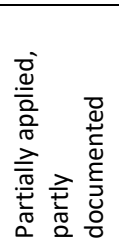 & 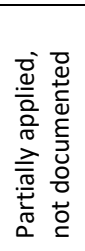 & 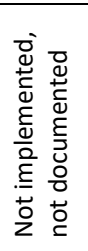 \\
\hline & 6 & 5 & 4 & 3 & 2 & 1 & $\mathbf{0}$ \\
\hline $\begin{array}{l}\text { The Municipality of Baghdad is able to adapt } \\
\text { to environmental conditions and } \\
\text { developments and adopts the necessary plans } \\
\text { to confront them }\end{array}$ & & & $\checkmark$ & & & & \\
\hline $\begin{array}{l}\text { Does the Municipality of Baghdad meet the } \\
\text { needs of civil society organizations in the field } \\
\text { of consulting (engineering or administrative)? }\end{array}$ & & & & & $\checkmark$ & & \\
\hline $\begin{array}{l}\text { Baghdad Municipality is opening up to other } \\
\text { organizations specialized in the field of work } \\
\text { in preparation for establishing strategic } \\
\text { twinning with it. }\end{array}$ & & & & & $\checkmark$ & & \\
\hline $\begin{array}{l}\text { The Municipality of Baghdad uses } \\
\text { technological techniques as tools to confront } \\
\text { and adapt to environmental changes. }\end{array}$ & & & & $\checkmark$ & & & \\
\hline Duplicates & $\mathbf{0}$ & 0 & 1 & 3 & & & $\mathbf{0}$ \\
\hline Score $=$ iterations $\times$ weights & $\mathbf{0}$ & 0 & 4 & 9 & & & 0 \\
\hline $\begin{array}{l}\text { Weighted arithmetic mean = result range } / \\
\text { group of iterations }\end{array}$ & & & & .75 & & & \\
\hline $\begin{array}{l}\text { Match extent = arithmetic mean } / \text { highest } \\
\text { weight }\end{array}$ & & & & 458 & & & \\
\hline
\end{tabular}


Gap Size = 1- Percentage of match extent

0.542

The results of the checklist in Table (5) above indicate that the Baghdad Municipality has achieved an average of (2.75) out of (6). This rate indicates that the Baghdad Municipality has reached a non-applied level partially documented from the paragraphs of the adaptation standard, with an application rate of (46\%) That is, which indicates the existence of a mismatch gap of 54\%, and this indicates the existence of a clear gap resulting from each of the following:

a. The Baghdad Municipality does not employ technological techniques as tools to confront and adapt to environmental changes.

B. The failure of the higher management in the Municipality of Baghdad to assess departments with community organizations to meet their needs in the field of consultations

Areas for improvement required

a. Working on preparing a specialized team to manage environmental changes.

$B$. The necessity of using technology and keeping pace with modern business models to avoid risks that occur during work.

3- A specific strategy: After an organization sets its mission, it moves to the next step, which is setting specific goals that focus on achieving that mission. Objectives are the specific and measurable outcomes of the initiative. The goals of the organization describe precisely how much "what" and "when" will be achieved. For example, it may be one of the multiple objectives of a community initiative concerned with promoting care and attention. This criterion includes (4) questions distributed into (6) weights related to (Baghdad Municipality's pursuit of formulating a clear and specific strategy) and as shown in the checklists for the implementation and documentation of the strategy standard. Specified and shown in Table (6) below:

\begin{tabular}{|c|c|c|c|c|c|c|c|}
\hline \multicolumn{8}{|c|}{ Table (6) a specific strategy checklist } \\
\hline a specific strategy & 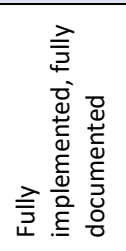 & 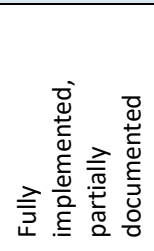 & 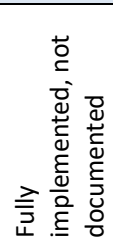 & 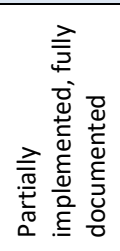 & 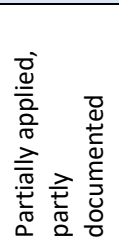 & 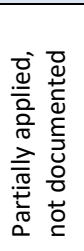 & 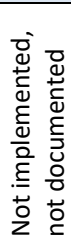 \\
\hline & 6 & 5 & 4 & 3 & 2 & 1 & $\mathbf{0}$ \\
\hline $\begin{array}{l}\text { The Baghdad Municipality is interested in } \\
\text { formulating a clear and specific strategy }\end{array}$ & & & & $\checkmark$ & & & \\
\hline
\end{tabular}




\begin{tabular}{|c|c|c|c|c|c|}
\hline $\begin{array}{l}\text { Often the goals set by the Baghdad } \\
\text { Municipality are achieved }\end{array}$ & & & & $\checkmark$ & \\
\hline $\begin{array}{l}\text { The appropriate method of work is } \\
\text { determined by the higher departments in the } \\
\text { Municipality of Baghdad. }\end{array}$ & & $\checkmark$ & & & \\
\hline $\begin{array}{l}\text { Helping to develop a specific and clear } \\
\text { strategy by the Baghdad Municipality to } \\
\text { succeed in implementing its objectives }\end{array}$ & & & $\checkmark$ & & \\
\hline Duplicates & $\mathbf{0}$ & 1 & 1 & 2 & $\mathbf{0}$ \\
\hline Score $=$ iterations $\mathrm{x}$ weights & $\mathbf{0}$ & 5 & 4 & 6 & $\mathbf{0}$ \\
\hline $\begin{array}{l}\text { Weighted arithmetic mean = result range } / \\
\text { group of iterations }\end{array}$ & \multicolumn{5}{|c|}{3.75} \\
\hline $\begin{array}{l}\text { Match extent = arithmetic mean } / \text { highest } \\
\text { weight }\end{array}$ & \multicolumn{5}{|c|}{0.625} \\
\hline Gap Size = 1- Percentage of match extent & \multicolumn{5}{|c|}{0.375} \\
\hline
\end{tabular}

The results of the checklist in Table (6) above indicate that the Baghdad Municipality has achieved an average of (3.75) out of (6). This rate indicates that the Baghdad Municipality has reached the level of implementation that is not applied. 62\%), meaning a gap of 38\%, and this result represents a large gap indicating causes, explained as follows: 1. There is no appropriate style in the work of management by the higher departments in the Municipality of Baghdad. 2. The Baghdad Municipality's reliance on routine administrative systems and not following developed systems that achieve the quality of service performance.

Areas for improvement required

a. Advanced information systems must be used to respond to any emergency changes and staff should be trained on them.

The Municipality of Baghdad shall instruct the Human Resources Department to provide individuals with high skills in the use of information technology by appointing vacant grades.

First: the conclusions

The fourth topic

\section{Conclusions and recommendations}

1- The weakness of the strategic measures to be taken by the senior management in the secretariat when strategic development is required.

2- The absence of a real system that evaluates the performance of individuals working in developing their skills and abilities.

3- The absence of a system for evaluating the performance of individuals for selecting candidates to fill positions from within the Baghdad Municipality

4- Lack of highly skilled employees to find strength and weakness points.

5- The lack of formulating a strategy for the Municipality of Baghdad for the purpose of ensuring its survival first and then developing its services in the future, and there is no monitoring of the implementation of those plans.

6- Failure to develop policies, strategies and contexts used in the Baghdad Municipality.

7- Baghdad Municipality not employing technological techniques as tools to confront and adapt to environmental changes.

8- Failure of the higher management in Baghdad Municipality to assess departments with community organizations to meet their consulting needs

\section{Second: Recommendations.}


To support the strategic development process of the Municipality of Baghdad and its departments that work in the direction of services and service projects for the city of Baghdad, the researcher recommends the following:

1. That the higher management in the Baghdad municipality attach importance to the contents of strategic development, expand it, understand it, recognize it, and identify the mechanisms of its implementation.

2. The continuous endeavor to diagnose the motives for strategic development in the Municipality of Baghdad to identify the areas of need for continuous strategic development and change.

3. Work to increase the awareness of senior and middle leaders and those in charge of it of the importance of strategic development and its positive impact on work performance in the Baghdad Municipality.

4. Opening effective investment opportunities that lead to increasing financial resources and utilizing them for the work of infrastructure projects.

5. Granting sufficient powers that enable the higher leaders in the Baghdad Municipality to take the necessary decisions and be able to accomplish the required work.

6. Following accurate scientific methods in selecting senior leaders, avoiding bias and favoritism, and considering competence and experience as a basic criterion in their selection.

7. Designing a reward system (financial or moral) based on achieving justice and equality among all individuals, and taking outstanding performance and the effort provided as the main criterion for granting the reward.

8. Increasing the researcher's Baghdad Municipality's interest in the administration's values, increasing work and encouraging its employees to increase (effectiveness, efficiency, and economy).

9. Allocating funds to the Municipality of Baghdad to support the comprehensive strategy and development of structures for municipal departments.

10. Create a real system that evaluates the performance of working individuals and develops their skills.

11. Selection of qualified candidates to fill the positions within the Baghdad Municipality

12. Defining and assessing the opportunities and challenges that the Baghdad Municipality can offer to the external environment, and the strengths and weaknesses contained in the internal environment.

13. The Municipality of Baghdad should benefit from the results of the strategic analysis in determining the main strategic directions of the organization.

14. Developing a vision for the Municipality of Baghdad, transforming it into tangible results, and developing its goals and mission.

\section{$\underline{\text { Sources }}$}

1- Al-Ghanim, Majed Abdullah, 2020, (The concept of strategy in the past and present and the possibility of its application in the public sector compared to the private sector), Al-Moder magazine for publication, Riyadh, Saudi Arabia.

2- Al-Ghalibi, Taher and Idris, Wael, (2015) (strategic management, an integrated methodological perspective), third edition, Wael Publishing and Distribution House, Amman, Jordan.

3- Fathallah, Khalsa (2012), (Total Quality Management as an Entrance to the Effect of Organizational Development in Higher Education), Masters Degree, Faculty of Economic and Business Sciences and Facilitation Sciences, University of Algiers, Algeria.

4- Amer, Sameh and Qandil, Alaa (2010), (Organizational Development), Dar Al Fikr, for Publishing and Distribution, Amman, Jordan.

5- Abu Al-Ward, Faten Adnan, 2015, (Degree of effectiveness of evaluation of UNRWA schools managers and its relationship to organizational development), a letter submitted to the College of Education, Islamic University, Gaza, to obtain a master's degree in the fundamentals of education

6- Taher, Mohsen Al-Ghalibi, and Ahmed, Ali Saleh, (2010), (Organizational Development, Introduction to Analysis, Concepts and Relationships, Strategies and Processes, Approaches and Techniques), First Edition, Dar, Wael Publishing and Distribution, Amman, Jordan.

7- Bouzouran, Saida, (2015), (The importance of organizational development in the institution), Al-Hikma Journal for Social Studies, No. 03, No. 06, Jumaa Lounisi for Publishing and Distribution, Blida, Algeria.

8- Nems, Bouzid, (2020), (The Role of Organizational Development in the Success of the Algerian Sports Professional System), Field Study, Academic Master Thesis, submitted to Mohamed Boudiaf University - Messila, Institute of Sciences and Techniques of Physical and Sports Activities, Specialization, Facilitating Human Resources and Facilities, Algeria .

9- Nasser. Jardat Muhammad, (2013), (Organizational Development: Concepts, Models and Foundations), Athraa House for Publishing and Distribution, First Edition, Amman, Jordan.

10- Al-Barasi, Fatima Abdel-Fattah, (2015), (Organizational development and its relationship to the effectiveness of administrative decision-making), a field study on a sample of some managers of the upper and middle departments in hospitals and public 
hospital medical centers in the city of Benghazi and a complementary study to obtain a master's degree in management Faculty of Economics, Benghazi, Libya.

11- Al-Salem, Moayad, and Adel, Saleh, (2006), (Human Resources Management - A Strategic Approach), Modern Book World for Publishing, Amman, Jordan.

12- Al-Qasim, Faisal Abdullah bin Muhammad, (2015), (Organizational development and its relationship to levels of organizational commitment from the point of view of the employees of the Riyadh region), a letter submitted to complete the requirements for obtaining a master's degree in administration, Naif Arab University of Science, Riyadh, Kingdom of Saudi Arab .

13- Ammari, Samir, (2013), (The Role of Organizational Development in the Success of the Change Process in the Enterprise), Case Study, for a Master's Degree in Management Sciences, from Mohamed Boudiaf University - Messila, Faculty of Economic and Commercial Sciences, Algeria.

14- Bilal, Khalaf Sakarneh, (2013), (Organizational and Administrative Development), first edition, Dar Al-Masirah for Publishing and Distribution, Amman, Jordan.

15- Ahmed, Ahmed Ibrahim, 2011, (Contemporary trends of development in schools), Arab Thought House for Publishing and Distribution, Cairo, Egypt.

16- Al-Sharif, Reem, 2013, (The Role of Administrative Development Management in Improving Job Performance), Master Thesis in Business Administration, King Abdulaziz University, Jeddah, Kingdom of Saudi Arabia.

17- Al-Sahn, Muhammad Farid, Al-Sayed, Ismail, and Sultan, Ibrahim, (2002), (Principles of Management), University House for Publishing and Distribution, Alexandria, Egypt

18- Mansour, Taher and Al-Khafaji, Nehme, (2010), (Organization Theory - Operations Introduction), Al-Yazuri House, for publication and distribution, first edition, Amman, Jordan.

19- Hammoud, Khader Kazem, (2010), (Knowledge Organization), first edition, Safaa House for Publishing and Distribution, Amman

20- Shtouh, Dalal and Tarshani, Siham (2011) (Intellectual Capital and its Role in Creating Organizational Development, an international forum entitled Intellectual Capital in Arab Business Organizations in Modern Economies), Chlef University, Algeria.

21- Samhan, Suhail Ahmad and Al-Wadi, Hammoud Hussein (2010), (Principles of Statistics for Economics and Administrative Sciences), Safaa House for Publishing and Distribution, Amman

22- Abu Bakr, Mustafa Mahmoud, Al-Naeem, Fahd Bin Abdullah, (2008) (strategic management, presence, thinking and decisions in contemporary institutions), University House, Alexandria.

23- Al-Taan, Dr. Hatem Fares, and Al-Fayyad, Majeed Hamid, (2013), (The effect of human resource management strategies in achieving strategic success), a field study in the Ministry of Transport, Al-Dinanir magazine.

24- Al-Tamimi, Iyad Fadel Muhammad, and Al-Khashali, Shaker Jarallah, The Jordanian Journal of Business Administration, Volume 11, Issue 3, (2015), (The Impact of the Elements of Strategic Alliance in Achieving Strategic Success), An Applied Study on Commercial Banks Operating in Jordan.

25- Al-Halalma, Muhammad Ezzat, and Al-Azzawi, Sami Fayyad (2009), (Intellectual capital and its impact on the causes of strategic success for business organizations), an exploratory study in Jordanian telecommunications companies

26- Al-Wondawi, Aws Bahjat, (2012), (The impact of technological capabilities on the success of the organization), an applied study on cellular telecommunications companies in the Hashemite Kingdom of Jordan, University of the Middle East, University of Business, College of Administration and Economics, Department of Business Administration, Master Thesis, Jordan.

27- Al-Lafi, Dr. Khaled Khalaf, Al-Khashman, Aysar Muhammad, 2020, (Application of high performance work systems and their impact on achieving strategic success), a field case study in Jordanian private universities, the Journal of the Islamic University for Economic and Administrative Studies.

28- Al-Khafaji, Nehme Abbas and Al-Hiti, Salah Al-Din (2009), (Analysis of the foundations of public administration) a contemporary perspective, Dar Al-Yazuri for Publishing and Distribution, Amman.

29- Al-Rikabi, Kazem Nizar (2004), (Strategic Management: Globalization and Competition), First Edition, Wael Publishing and Distribution House, Amman.

30- Al-Dulaimi, Samar Salah Shaker (2013),) analyzing the relationship between the management of wisdom and time management and its reflection on strategic success, an analytical exploratory study of the opinions of a sample of administrative leaders in colleges of the University of Baghdad (, a letter submitted to the Board of the College of Management and Economics - University of Karbala (G. It is part of the requirements for obtaining a master's degree in business administration.

31- Al-Enezi, Amira Khudair Kazim (2010), (The role of the dimensions of customer relationship management and creative thinking in achieving strategic success), a case study in the men's clothing factory in Najaf, a master's thesis in business administration (G.M.), an introduction to the College of Management and Economics, University of Kufa .

32- Abu Radan, Iman Bashir Muhammad Mustafa, (2005), "The Strategic Orientation and Its Impact in the Areas of Change", an exploratory study in some industrial companies in the city of Mosul, Master's Thesis in Business Administration (GM), submitted to the College of Management and Economics, University of Al Mosul . 
33- Alhyasat Waleed Mohammad Kayed\& Sharif Zainon Mat. (2016), "The relationship between strategic leadership and organization performance in Jordan industrial estates company", 3rd International Conference on Applied Science and Technology, AIP Conference, 020023-1-020023-5.

34- Dyson, R.G. \& Foster, M.J. (1980) 'Effectiveness in strategic planning', European Journal of Operational Research, , 163-170.. 35- Dyson, R.G. (2000) 'Strategy, performance and operational research', Journal of the Operational Research Society, $51,5-11$.

36- Dyson, R.G. \& Foster, M.J. (1983) 'Effectiveness in strategic planning revisited', European Journal of Operational Research, $12,146-158$

37- R.G. Dyson / European Journal of Operational Research 2004, (Strategic development \& Swat analysis) , At the Universlty of .

38- Robert G. Dyson, Jim Bryant, John Morecroft and Frances O'Brien, 2007), The Strategic Development Process .

39- E Tapinos, RG Dyson, and M Meadows, 2011, Does the Balanced Scorecard make a difference to the strategy development process, Aston Business School, Birmingham, UK; 2Warwick University, Coventry, UK; and 3Open University,Milton Keynes, $U K$.

40- Argyris C and Schon DA (1978). Organizational Learning: A Theory of Action Perspective. Addison-Wesley: Reading, MA .

41- Dimitrakopoulos, Roussos. (2018), "Advances in Applied Strategic Mine Planning", McGill University, Canada.

42- Hodgkinson GP, Whittington R, Johnson G and Schwarz M (2006). The role of strategy workshops in strategy development processes: Formality, communication, co-ordination and inclusion.

43- Long Range Plann 39: 476-496. Modern oxford,(2010), "published by oxford university prees, "New York.

44- Thomas, Tammara P, (2013), "The Effect of Personal Values, Organizational Values, and Person - Organizational Fit on Ethical Behaviors and Organizational Commitment Outcomes among Substance Abuse Counselors"A Preliminary Investigation - University of Lowa.

45- Hesham A. E., Magd, Salah ElD in Adam Hamza, (2007), Critical success factors for achieving Organizational excellence in the Middle East: Engineering firms perspectives, E-TQM College Working Paper Series, Vol.1, Iss. II.

46- Jones, Gareth R., " Organizational Theory, Design, and change " , 6 th ed., Pearson Prentice Hall ,Inc., Upper Saddle River, New Jersey, 2010.

47- Katz,Jeromea.\&Green, Richard p. "Entrepreneurial Small Business" ,Mc Graw-Hill,Irwin,New York, NY,2007.

48- Kasten, Jennifer Murphy,(2006), "Determinants of organizational change :the impact of institutional and market forces on compliance with federal regulations in opioid treatment programs", www.lib.ncsu.edu/theses/availablelet.

49- Daft, R. L., (2001), "Organization: Theory \& Design", 7th ed., (Ohio: South Western). 